Christian Danz*

\title{
Religious Diversity and the Concept of Religion
}

\section{Theology and Religious Pluralism}

https://doi.org/10.1515/nzsth-2020-0004

Summary: The article deals with the concept of religion in the contemporary theology of religions. Many theologians in the current debate work with a general concept of religion. Such a conception of religion unifies the distinctive religious diversities. This article argues that against the background of the previous debate, a theology of religions must proceed from a concept of religion as communication. This concept emerges out of the Christian religious tradition: it carries a particular meaning and hence should not be treated as universally applicable. Starting with a concrete concept of religion, a theology of religion has the task neither to give a foundation for other "religions", nor that of Christianity. Only this could be a basis for a real pluralistic conception. From this starting point follows the question on how other religions understand religion.

Keywords: Religious Diversity, Concept of Religion, Theology of Religions

Zusammenfassung: Der Artikel thematisiert den Religionsbegriff in der gegenwärtigen religionstheologischen Debatte. Viele Autoren arbeiten mit einem universalen Begriff der Religion. Mit ihm ist jedoch das Problem verbunden, die Diversität des Religiösen monistisch zu reduzieren. Demgegenüber wird die These vertreten, in der Religionstheologie von einem Verständnis von Religion als Kommunikation auszugehen, auf einen universalen Religionsbegriff $\mathrm{zu}$ verzichten und diesen auf die christliche Religion zu beschränken. Religionstheologie hat weder die Aufgabe andere Religionen noch das Christentum zu begründen. Erst damit ist die Grundlage für eine Wahrnehmung der Pluralität des Religiösen geschaffen. Gegenstand einer Theologie der Religionen ist damit die Pluralität der Fassung des Religiösen in den diversen Religionen.

Schlüsselwörter: Diversität des Religiösen, Religionskonzepte, Theologie der Religionen

\footnotetext{
*Corresponding author: Prof. Dr. Christian Danz, Protestant-Theological Faculty, University of
} Vienna, Schenkenstraße 8-10, A-1010 Vienna, E-Mail: christian.danz@univie.ac.at 
A fundamental change underlies religious life in the contemporary world. "Today the reality of other religions no longer exists only across the border, in distant lands. It has moved into neighborhoods throughout the world, but nowhere more unavoidably than in America and Europe."1 Through transformations of society, culture and religions, relative homogeneous religious milieus are gone. Today we live in a global world with many religions and religious traditions. Theoreticians of religions have diagnosed an overlapping of religious traditions as a result of global symbol transfers in the world-wide-web and global religious markets. ${ }^{2} \mathrm{Mi}$ gration led to a close proximity of religious and cultural diversity in many cities in the world.

Like in other academic disciplines that deal with religious phenomena, we also face in theology, since the 1980's, a new and fresh attention given to issues related to religion and religious pluralism. Against the so-called Christo-centrism of the protestant theology of the $20^{\text {th }}$ century and the inclusivism of the RomanCatholic church and theology, the so-called pluralistic theology of religions has worked out a new model of theology. ${ }^{3}$ They understand that the task of theology is to give a new interpretation of Christianity among the non-Christian religions that conquers the old idea of an absoluteness of Christianity. ${ }^{4}$ Against this, pluralistic theologians were convinced, that theology must give a foundation of the same worth of all great world religions. This is the task of theology in a global pluralistic age. "'Religious pluralism' designates a specific theory and evaluation of religious diversity. [...] 'Religious pluralism' [...] is not simply an interpretation of religious diversity, but it is itself a religious interpretation." ${ }^{5}$ Theology of religions,

1 Paul F. Knitter, Introducing Theologies of Religions, New York: Orbis Books 2002, p. 5.

2 Cf. Peter Beyer, Religions in Global Society, London/New York: Routledge 2006; Christian Danz, Die Deutung der Religion in der Kultur. Aufgaben und Probleme der Theologie im Zeitalter des religiösen Pluralismus, Neukirchen-Vluyn: Neukirchener Verlag 2008, pp. 17-40; Friedrich Wilhelm GraF, Die Wiederkehr der Götter. Religion in der modernen Kultur, München: C. H. Beck 2004. 3 Cf. John Hick/Paul F. KnitTer (Ed.), The Myth of Christian Uniqueness. Toward a Pluralistic Theology of Religions, New York: Orbis Books 1988. To the contemporary debate of theologies of religions cf. Knitter (see Fn. 1); Reinhold Bernhardt, Ende des Dialogs? Die Begegnung der Religionen und ihre theologische Reflexion, Zürich: Theologischer Verlag 2005.

4 Cf. Ernst Troeltsch, Die Absolutheit des Christentums und die Religionsgeschichte (1902/1912), mit den Thesen von 1901 und den handschriftlichen Zusätzen (= Ernst Troeltsch, Kritische Gesamtausgabe, Bd. 5), ed. by Trutz RendtorfF in cooperation with Stefan Pautler, Berlin/New York: de Gruyter 1998. Cf. Reinhold Bernhardt / Georg Pfleiderer (Ed.), Christlicher Wahreitsanspruch - historische Relativität. Auseinandersetzung mit Ernst Troeltschs Absolutheitsschrift im Kontext heutiger Religionstheologie, Zürich: Theologischer Verlag 2004.

5 Perry Sснмidt-Leukel, Religious Pluralism \& Interreligious Theology. The Gifford Lectures - An Extended Edition, New York: Orbis Books 2017, p. 1. 
as Perry Schmid-Leukel emphasizes, is a theological task and not a question of the studies of religions.

However, the pluralistic model by John Hick and other pluralistic theologians is insufficient. The model gives neither a description of religion nor of the diversity of religions. Also other conceptions of a theology of religions like the comparative theology or so-called acceptance model ${ }^{6}$ do not give a solution to the understanding of religions. All of these mentioned models do not allow the connection between the distinctiveness of Christianity with recognition of other religions. The reason for this is the concept of religion. If religion is understood as a universal anthropological category, then the concept of religion reduces all religious diversity to a low common denominator, whatever it may be. In all religions and religious traditions, we find the same essence. This means, such a theology of religions flattens distinctive religious diversities into a monistic reformulation. But such a theology couldn't provide us with an explanation for a concrete religion like Christianity or Judaism. Therefore, a theology in the age of pluralism must work out a concept of religion that allows the description of the distinctiveness of Christianity while at the same time recognizing other religions as such in their own idiosyncrasy. The task of theology is not to give a foundation of religious pluralism or of other religions including Christianity. Rather theology must explain how Christian religion functions in the context of other religions and nonreligious cultures.

Such a conception of a theology of pluralism is to be discussed within the following considerations. The first part consists of the contemporary debate about theology of religions and the problems of such conceptions. In the second part, the discussion consists of a concept of religion that is able to give a solution for the problems of a theology of religious pluralism. In the third part, an explanation of the structure of a theology of religious pluralism is given.

\section{Religion in the Contemporary Theology of Religions}

Important for the current debates of theology of religions is the so-called pluralistic model by John Hick and other theologians. ${ }^{7}$ The pluralistic theologians under-

6 See Knitter (see Fn. 1), pp. 173-237.

7 Cf. John Hick, The Interpretation of Religion. Human Answers to the Transcendent, New Haven: Yale University Press 1989; Schmidt-Leukel (see Fn. 5). To the pluralistic model see Knitter (see 
stand the pluralist model as an alternative to the previous one operative in the debate about Christianity in relationship with other religions. Neither the socalled exclusivism nor inclusivism models explicitly or implicitly places Christianity in parity to religious otherness. In both positions, there is - in the end only one true religion, namely Christianity. All other religions are wrong. Such a view of religious otherness is not plausible any longer. In a pluralistic society and culture where people from different religions live side by side with non-religious people, making the claim of one particular religion to be the true religion makes no sense. And how could Christians learn or discuss with members of other religions when they claim Christianity alone has the absolute truth and all other religions are false? This is only possible, if possible at all, within the pluralist model. This is a theological task, namely to give a theological foundation for the equality of the post-axial religions. ${ }^{8}$ For the pluralistic model, the distinction is between the transcendent absolute and the cultural interpretations of manifestations of the absolute. "We now have to distinguish between the Real an sich and the Real as variously experienced-and-thought by different human communities. In each of the great traditions a distinction has been drawn, though with varying degrees of emphasis, between the Real [...] in itself and the Real as manifested within the intellectual and experiential purview of that tradition." The distinction is. On the one side, there is the transcendent absolute as the absolute ground of all religions, and on the other side, there are the diverse religious interpretations, which are all human answers to manifestations of the transcendent absolute. Connected with such a religious answer, and based on a religious experience which is always a culturally formed interpretation, ${ }^{10}$ a shift from "self-centredness to Reality-centredness"11 takes place. If all post-axial religions are human interpretations of the manifestations of the transcendent absolute, and no one has the privileged access to the absolute, then within all religions there is an equal shift from self-centredness to reality-centredness that takes place. No one has full ac-

Fn. 1), pp. 109-169; Christian DAnz, Einführung in die Theologie der Religionen, Wien: LIT 2005, pp. $70-77$.

8 Cf. Hick (see Fn. 7), 21-35. To the post-axial religion see also Robert Bellah, Religion in Human Religion. From the Paleolithic to the Axial Age, Harvard University Press 2017.

9 Hick (see Fn. 7), 236. Cf. Schmidt-Leukel (see Fn. 5), 25: „We can therefore never experience the Real as it is in itself, that is, in its infinity, but only in the finite ways predetermined by our limited cognitive capacities, that is, as the particular personae and impersonae of the religions. This conclusion [...] is primarily derived from the metaphysical affirmation [!] of the transcendence of God or Ultimate reality, an affirmation that is found in all the major religious traditions."

10 Hick (see Fn. 7), 140: „But in fact all our seeing is seeing-as and, more broadly, all conscious experience is experience-as." Cf. also ibd., 153-171.

11 Нick (see Fn. 7), 240. Cf. also ibd., 32-55. 
cess to the Real, because the Real is transcendent, which means they couldn't know.

For the pluralistic model all great religions of the world have the same worth, they are all equal. The foundation for this claim is the transcendent absolute that lies beyond all concrete religions and their diverse self-descriptions. But how is it possible to know that the transcendent Real is the ground for all religions if this absolute is transcendent and couldn't be known by anyone? Hick's answer to this question is that the Real is a postulate and a hypothesis. Only such a postulate could give the explanation of the same worth of all post-axial religions and reject the naturalistic critique of religion. ${ }^{12}$ As we have seen, the pluralistic model is a construction to provide a foundation for the equality and same worth of other religions like Christianity. There are many questions which Hick's model raises. First of all, the pluralistic model is confronted with the problem that the equality of religions is located beyond the concrete religions. That means that pluralistic theology constructs the same worth of all post-axial religions apart from their concrete self-understanding. So the mutual recognition of the religions has no place in the religions itself but only in the theology of religions. The view of the diversity of religions comes from pluralistic theology, and it is not the point of view of the religions itself. Hick's argument that the post-axial religions making a distinction between gods and the transcendent absolute is meant in a metaphysical manner. But in such a substantial sense the distinction is not plausible. The God above God, to stress Paul Tillich's formulation here, ${ }^{13}$ means a function for the religion and not a metaphysical substance beyond the images of God. Further, the Real beyond the concrete gods and the absolutes of the diverse religions is a postulate. The model works with a religion (namely the transcendent real which is for itself religious) apart from the concrete religions, with a metaphysical divine apart from its religious appropriation. It makes no sense to postulate a transcendent absolute that is totally unknown and at the same time to claim that this absolute is the ground of all religions. A consequence of this is that all religions happen to be the same. The diversity of the religious traditions of the world is

12 Cf. НІск (see Fn. 7), 243: „In partial agreement but also in partial disagreement with him [sc. Kant's postulate of God, who couldn't be experienced], I want to say that the Real an sich is postulated by us as a pre-supposition, not of the moral life, but of religious experience and the religious life, whilst the gods, as also the mystically known Brahma, Sunyata and so on, are phenomenal manifestations of the Real occurring within the realm of religious experience." Cf. also ibd., 249. See also KnitTer (see Fn. 1), 115: "That's why he [sc. Hick] proposed his revolutionary view as a hypothesis. It's the best way to make sense of the data of humankind's religious history."

13 Cf. Paul Tillich, The Courage to Be. Third Edition, New Haven/London: Yale University Press 2014, pp. 171-175 
merely surface appearance. In their essence all religions are common; they are equally valid answers to the manifestation of the absolute. In this way the foundation of religious pluralism is at the same time the abolition of pluralistic diversity. There is only one true religion in various forms, but no religious diversity.

The pluralistic model is not pluralistic, rather monistic. It gives a foundation for the same worth of the post-axial religions with Christianity in a theological construction. But such a theological approach leads not to an understanding of both Christianity and religion. If theology of religions is, as Hick mentioned, a theological task and not a question of the study of religion, then the pluralistic model is not able to explain how Christian religion functions. The reason for this is that the pluralistic theology of religion does not construct religion from the perspective of a concrete religion.

In the further debate about theology of religions we could find the attempt to give a solution to the afore mentioned systematic problems of the pluralistic model. There are two main types, the first being that of forms of mutual inclusivism, and the second being of the so-called comparative theology. Against the pluralistic theology of religions, they point out that theology of religions must start from a concrete religious point of view. To proclaim a transcendent absolute that is apart from the concrete religious view of the world and to other religions is not really helpful. This is an abstract construction that gives no explanation on how the concrete relations between Christianity and other religions work. Conceptions of a mutual inclusivism reject the construction of the transcendent real beyond the gods and absolutes, but it retains the intention of the pluralistic model to give a foundation of the same worth for non-Christian religions alongside Christianity. This is only possible through the postulate of the same God behind the religions. ${ }^{14}$ This God is not the Real of Hick, this God is the God of a concrete religion. But when all religions have their foundation in the Christian concept of the triune God, how is it then possible to find in other religions no more than a disguise of Christianity? Within this conception of the theology of religion, the non-Christian religion could not be constituted with its own sense of worth and otherness. The members of other religions are simply 'anonymous Christians'.

On the other hand, comparative theology is different to the theology of religions that we have discussed above. It rejects this form of the theology of religions, and also universal conceptions of religions like the concept of a universal

14 Cf. S. Mark Heim, The Depth of the Riches: Trinity and Religious Ends, in: Theology and the Religions. A Dialogue, ed. by Viggo Mortensen, Grand Rapids/Cambridge: Wm. B. Eerdmans 2003, pp. 387-402. Heim's goes out from the Christian concept of trinity as the ground of all religions and its conceptions of religious ends. 
religious experience. ${ }^{15}$ Comparative theology of religions must start with the encounter of a different religion. It must begin with dialogue instead of a theological foundation of the religious otherness. ${ }^{16}$ We see that there is a methodological change in the comparative theology of religions. Here theology must begin with the study of texts or rituals or narratives from another religion, and then go back to the text or narratives of the Christian religion itself. In this way dialogical encounter with religious otherness opens a new view and new questions to its own religion. Comparative theology aims towards a deeper understanding of Christianity in the light of another religion. But a critical issue emerges: is such a theology still theology and not the study of religion? And how is it possible to compare elements of two different religions? How does the theologian know, that the text or the narrative from the other religion is a religious text? He must presuppose this. And is not comparing always a construction of otherness? Also, comparative theology presupposes a concept of religion that is uniform. But there is no explanation about this uniform concept of religion. ${ }^{17}$

As we have seen, the current debate of the theology of religions works with a general concept of religion as a foundation of a theological encounter with other religions. This presupposed concept of religion undermines the diversity of religions because it unifies, and consequently neglects, the diverse religious traditions. What follows from this is that the task of a theology that is open to pluralism must find a different form. This necessitates firstly a new understanding of religion as the content of theology, and secondly a rejection of a universal conception of theology which is inclusive.

\section{Religion as Communication}

In the contemporary debates of the theology of religions, religion is understood as a relation to one and the same transcendent absolute behind the symbols and images of concrete religions. Because of this relation to the absolute or the Real, as Hick had named as transcendent, religion is universal. The other models also work in a modified way with such a common ground of religions. Such a universal concept is not without problems, and it is criticized in the debates about religion.

15 Cf. James L. Fredericks, A Universal Religious Experience? Comparative Theology as an Alternative to a Theology of Religions, in: Horizons 22 (1995), pp. 67-87.

16 Cf. Knitter (see Fn. 1), p. 203.

17 Cf. Klaus von Sтолсн, Komparative Theologie als Wegweiser in der Welt der Religionen, Paderborn/München/Wien: Ferdinand Schöningh, 2012. Von Stosch works like mutual inclusivists with a God behind the diverse religions. 
For such an understanding of religion consists of the idea that all world religions are only examples of one generalized version. The uniformity of the concept dissolves the diversity of the historical religions.

So is really no surprise to see that the general concept of religions is criticized in the $20^{\text {th }}$ century. The protestant theology in the age of Enlightenment established religion as the basis of theology as science. This was necessary because the old foundation of theology through the concept of God doesn't work against the critique of knowledge from Immanuel Kant and others. What follows is that religion, no longer God, is the starting point of theology. In the debates around 1800, religion is understood as an essential part of the human or the human consciousness. If this is the fact, then human religion is universal. Everybody is religious because religion is an attribute of being human. That means: the concept of religion justified the generality of religion. Generally speaking, within the $20^{\text {th }}$ century concepts of religion became problematic against the background of the transformations of society and culture. On the one side we find a critique of religion in the theology of the early $20^{\text {th }}$ century. This theological critique of religion is not a critique on religion as such, rather it is a critique on the supposition that religion is an essential part of human being. The new descriptions of religion in the protestant theology after World War One (by Karl Barth and others) understood religion as an act that has no ground in human being. Religion is only real as an act. The theological description of this act as revelation of God means just this: religion emerges as an act of humans without a ground in human being.

On the other hand, general concepts of religion are criticized in the philosophy of religion and the studies of religion. ${ }^{18}$ Many theorists of religion argue that religion is a modern concept that is unknown both in earlier centuries and outside the western culture. Religion was invented by Protestant theologians during the time of the Enlightenment. Thus the concept of religion has a function for the selfdiscussion of Christianity in the modern age and cannot be used for different cultures, for example, Asian culture. ${ }^{19}$ These different cultures don't know religion in the sense of modern Christianity with all the differentiations between religion and politics, religion and art, religion and economy and so on. If someone describes Hinduism as religion, one potentially partakes in colonialism.

What follows from this for the concept of religion? First of all, the task to work out a new understanding of religion that includes the critiques of a general con-

18 Cf. Robert A.SEgAL, Theories of Religion, in: The Routledge Companion to the Study of Religion, ed. by John R. Hinnells, London/New York: Routledge 2005, pp. 49-60; Martin RieSEBRodt, Cultus und Heilsgeschehen. Eine Theorie der Religionen, München: C. H. Beck Verlag 2007.

19 Cf. Brent Nongri, Before Religion. A History of a Modern Concept, New Haven/London: Yale University Press 2013, p. 5. 
cept of religion based on being human. Religion is not a sort of human necessity; rather the emergence of religion is contingent and underlies a process of differentiation. Theology must give a description of the Christian religion and not religion in general. In the concept of religion, theology constructs the Christian religion as a self-relation. The view of the participants of the Christian religion must be a part of the concept of religion. So the task of theology is to give an explanation as to how the Christian religion functions in the view of the participants of the Christian religion. Against this background, religion must be construed as a happening of communication. This means religion emerges as such in the religious use of language through the participants of the religious language, in the religious meaning of the communication through humans.

In this proposal of the understanding of religion as communication, the starting point is neither a religious subject nor religious content. ${ }^{20}$ Both are elements of religion as religious communication. A religious subject and religious content we find only within the Christian religion. Both are not presuppositions for a foundation of religion as we found in the debates since 1800. Religion lies in a triadic happening or event. First, all religion depends upon religious communication which is given as a part in the culture. Second, without appropriation of the religious language through humans no religion is possible, and third, religion must be articulated through human discourse. It is important that religion only emerges in the interrelation of all three elements.

The emergence of the Christian religion presupposes the tradition of Christianity, the narratives of the memory of Jesus Christ as its own sphere of communication within the culture, because religion depends always upon religious expression and communication. That doesn't mean a predetermined faith or something else. Rather, what is presupposed is Christian religious communication as the memory of Jesus Christ. Without this the Christian religion could not have originated. But the tradition of Christianity as such is not religion. It's a hint towards religion, but not religion. The reason for this is that the tradition of Christianity is always able to be used by humans within a non-religious sense, for example within either a historical, aesthetical or a political sense. Thus, religion presupposes a determined tradition, namely the memory of Jesus, but it's impossible to deviate actual religion from this tradition. For there is also within the emergence of religion a necessary second element, namely the appropriation of the traditional Christian language through concrete humans. Without this, without individual

20 To this concept of religion see Christian Danz, Gottes Geist. Eine Pneumatologie, Tübingen: Mohr Siebeck 2019, pp. 118-130; Folkart WitTeкind, Theologie religiöser Rede. Ein systematischer Grundriss, Tübingen: Mohr Siebeck 2018, pp. 29-55. 
appropriation of the religious language and one's own self understanding of religion as such, religion is impossible. The personal usage of the memory of Jesus Christ as a religious usage is constitutive for Christian religion. Religion is a specific usage of communication, and only if this happens we could then say that there is a religion. This is necessary insofar as it is impossible to recognize religion on contents like God. But the appropriation of the Christian tradition must be articulated from humans for a representation of its own religious self-understanding. Without representation, there is no understanding. This is also the case for religion. Only if this happens, then we have religion as its own sphere in culture.

Christianity as religion, as we have seen, has an inner triadic structure. As religion it emerges as the memory of Jesus Christ only in the interrelation of all three elements. Within this understanding of religion there are some interconnected consequences: First, religion is a self-relation. Christian religious communication refers only to itself as religious communication. In this way religion is absolute, and not within regard towards its contents. Absoluteness is an expression of the self-relation of the religious communication. Second, the contents of the Christian religion like God, Christ and the Holy Spirit, are elements of the Christian religious communication and not presuppositions of the religion. They have a function for the religious communication because they describe in and for the religion how the Christian religion emerges and functions. God, Christ and the Holy Spirit are not objects outside the religion. Third, the knowledge of religion is an essential element of the religious act. Without the knowledge to practice religion, no Christianity as religion is possible. Therefore an unknown or implicit religion, or an anonymous Christianity is not a helpful construction of religion. From this follows the recognition of non-religious self-understanding as a legitimate understanding through theology. And from this proposed concept of religion also follows the recognition of other and diverse forms of religion other than Christianity. The reason for this is that Christian religion emerges only in the religious communication as a self-transparent happening. So Christianity exists only in the religious transfer of the religious memory of Jesus Christ.

The task of theology is to construct the Christian religion as a self-transparent happening of Christian religious communication. We must now see what follows from such an understanding of religion for the project of a theology of religions.

\section{A pluralism open Theology}

The task for theology is to construct a concept of the Christian religion. Theology must explain how Christian religion functions. But it's not the task of theology to give a foundation of religion. Neither the Christian religion nor other religions 
must be founded through theology. This is impossible because all foundations of religion are circular. ${ }^{21}$ Religion has its foundation and its worth in itself, in the happening of the religious communication. Theology in its construction of the Christian religion explains religion in its triadic structure as we have discussed above. Only in this sense is theology as science possible. Theology uses the contents of the Christian religion in a reflexive manner and not as objects. God, Christ and the Holy Spirit have a reflexive function for the Christian religion and they are only related to the Christian religion. On this theology develops its inner truth of the Christian religion as its own view of the world alongside other interpretations of the world like politics, economy, art and so on.

If theology is related to the Christian religion and tasked to explain God, Christ and the Holy Spirit as elements of the Christian religion, then the theology of religions must give up the postulate of an absolute or a God behind the religions as their common ground or foundation. Such a postulate is not really helpful for a theology of religions because it reduces the diversity of religions in a monistic manner. So for example, the Christian religion emerges from Judaism and was a part of the Jewish religion.22 The God of Jesus was the God of Israel, and also the early Christians began in the ancient Jewish religion. But in the further development both religions are separated and develop their own understanding of God with different functions in both religions. The difference between Christianity and Judaism lies not with regards towards the content of God, but in different functions of God. Both Judaism and Christianity are their own religions with their own images of God, community and so one.

At the same time theology must give up to desire to construct a universal concept of religion. The concept of religion which theology works out is the concept of Christianity as religion. This is not a universal concept. The concept of religion is related only to Christianity. There is no uniform or general concept of religion. Other religions have their own understanding of what 'religion' means. With this, which is the consequence of the proposed program of theology as a construction of the Christian religion as religious communication, we have a basis for a theology of a plurality of religions.

A theology of religions must be able to explain the distinctiveness of Christianity and also of its inner absoluteness. At the same time the Christian religion like other religions experiences underlying transformations. The identity of Christianity is not a substantial identity. Rather the identity of the Christian religion is a self-

21 Cf. Paul Tillich, Systematic Theology, Vol. I, Chicago: The University of Chicago Press 1951, pp. 8-11.

22 Cf. Christian Danz, Jesus von Nazareth zwischen Judentum und Christentum. Eine christologische und religionstheologische Skizze, Tübingen: Mohr Siebeck 2020. 
description that is always changing. Yet in Christianity, the question of what is the essence of the Christian religion is a question with many different answers. They all depend on the point of view of those who give the answer. If a theology of religions starts with a rejection of a universal anthropological concept of religion, then theology could recognize the diversity of religions. This is only possible with a renunciation of the postulate of a God behind God in a metaphysical or substantial manner. ${ }^{23}$ Theology is not metaphysics, rather a construction of religious communication in Christianity. The task of a theology of religions is not to minimize the differences between religions. If theology would do this, then it would be impossible to recognize other religions as independent religions. But this is exactly the case within the pluralistic model, within the new inclusivism, and also comparative theology. They all proceed from a concept of God, which lies behind the concrete religions.

What follows from the considerations is a new understanding of the task of a theology of religions. Theology of religions must not, as we see with John Hick and Perry Schmidt-Leukel, propose to give a theological foundation of all great world religions. This is impossible. Theology explains the Christian religion in the horizon of other religions. The theme of such an investigation is firstly the concept of religion. If there is no uniform concept of religion, then the task of a theology of religions is to examine how other religions understand itself as religion. What do they mean by "religion"? And how does religious communication function in other religious traditions? This is only possible in a discourse with members of other religions. This is now not an investigation about the contents of another religion, because the differences between religions lies not only in the content. God, for example, has in different religions like Christianity and Judaism different functions and meanings in the whole hermeneutic system of each religion. There is no common God which is received in both religions as merely a different form or variation of the same. This is an abstract postulate which doesn't explain how concrete religions functions. And this is not the view of the concrete religions and its central symbols. To start with the difference between religions means the task for searching for what is in common, but not to begin with it. But as we have seen the commonality of religions lies not in the contents. You could always give the same contents a different meaning. There is no change in the contents if you read for example the new testaments gospels as a discourse about Judaism in Judaism. ${ }^{24}$

23 Also Paul Tillich's famous formula of a God above God means not a substantial God behind the God of the Christian religion. The religious critic of the concrete images of God has a function for the religion and describes the reflexive structure of the religious act. Cf. Tillich (see Fn. 13), pp. 158167.

24 Cf. Daniel Boyarin, The Jewish Gospel. The Story of the Jewish Christ, New York: The New Press 2012. 
In the $21^{\text {th }}$ century all theology works against the background of religious diversity. If theology would give an analysis of the contemporary religious world and her transformations, then it is not possible if theology uses a concept of religions that has abolished religious diversity. So the theme of a theology of religions must consist of what the different understandings of what religion means in the diverse religious traditions. ${ }^{25}$

25 I express my thanks to Joshua Ramos (Denver/Vienna) for help in translating and also to YoungHo Chun (Kansas City). 